University of Nebraska - Lincoln

DigitalCommons@University of Nebraska - Lincoln

Space, Cyber, and Telecommunications Law

Program Faculty Publications

Law, College of

2011

Space Tourism, Private Spaceflight and the Law: Key Aspects

Frans G. von der Dunk

University of Nebraska - Lincoln, fvonderdunk2@unl.edu

Follow this and additional works at: https://digitalcommons.unl.edu/spacelaw

Part of the Air and Space Law Commons, European Law Commons, International Law Commons, and the Other Legal Studies Commons

von der Dunk, Frans G., "Space Tourism, Private Spaceflight and the Law: Key Aspects" (2011). Space, Cyber, and Telecommunications Law Program Faculty Publications. 60.

https://digitalcommons.unl.edu/spacelaw/60

This Article is brought to you for free and open access by the Law, College of at DigitalCommons@University of Nebraska - Lincoln. It has been accepted for inclusion in Space, Cyber, and Telecommunications Law Program Faculty Publications by an authorized administrator of DigitalCommons@University of Nebraska - Lincoln. 


\title{
Space Tourism, Private Spaceflight and the Law: Key Aspects
}

\author{
Frans G. von der Dunk (fvonderdunk2@unl.edu) \\ Space and Telecommunications Law Program, University of Nebraska-Lincoln, College of Law, Lincoln, Nebraska, U.S.A.
}

\begin{abstract}
The arrival of 'space tourism,' or more appropriately 'private spaceflight,' requires the law of outer space to change and adapt to this revolutionary development, as deriving precisely from the principled private participation in these activities. After defining the proper concepts, this paper discusses key legal aspects of authorization and supervision, liability and registration, and how they re.ect and impact on space tourism. Key legal aspects related to certification of craft, crew and passengers, while not yet much articulated at the international level will also be touched upon precisely in order to demonstrate that the law could well be driven first and foremost by national legislative interests on a domestic level, before (possibly) reaching the level of international law. The possible use of air law or even adventure tourism law to regulate relevant activities is also touched on.
\end{abstract}

Article history: Received October 29, 2010; accepted April 18, 2011; available online September 6, 2011

\section{Introduction: A New Kid on the Block}

'Space tourism' is often hailed as giving rise to a revolution in the accessibility of humans to the hostile and, in principle, endless realm of outer space. Inevitably, this is already leading to, and will continue to drive even further, fundamental discussions on the law of outer space as it currently stands, and how it should change to adapt to such revolutionary developments. Indeed, it might well augur in a third era in the history of humanity's endeavors in outer space.

In a first era the categories of players and stakeholders in space activities were fairly limited. Essentially only a handful of governments or their agencies (and occasionally intergovernmental organizations - still public bodies legally speaking) were involved in the various roles of launching space objects, operating and/or controlling them. Private enterprise was limited to a role as manufacturer in the service of those public entities, as downstream customer of space-based applications realised by them, or provider of subsidiary services for their benefit. Consequently, the five main UN space treaties concluded in the late 1960s and 1970s were considered appropriate in their focus on the rights and obligations of these state agencies. ${ }^{1}$ Private sector involvement required fairly little national implementation of international obligations, as those treaties also, generally speaking, dealt with space activities themselves as opposed to preparatory, downstream application or supportive activities.

\footnotetext{
${ }^{1}$ The first four of these are relevant to space tourism and manned spaceflight: (1) the Treaty on Principles Governing the Activities of States in the Exploration and Use of Outer Space, including the Moon and Other Celestial Bodies (hereafter Outer Space Treaty), London/Moscow/Washington, done January 27, 1967, entered into force October 10, 1967; 610 UNTS 205; TIAS 6347; 18 UST 2410; UKTS 1968 No. 10; Cmnd. 3198; ATS 1967 No. 24; 6 ILM 386 (1967); (2) the Agreement on the Rescue of Astronauts, the Return of Astronauts and the Return of Objects Launched into Outer Space (hereafter Rescue Agreement), London/Moscow/Washington, done April 22, 1968, entered into force December 3, 1968; 672 UNTS 119; TIAS 6599; 19 UST 7570; UKTS 1969 No. 56; Cmnd. 3786; ATS 1986 No. 8; 7 ILM 151 (1968); (3) the Convention on International Liability for Damage Caused by Space Objects (hereafter Liability Convention), London/Moscow/Washington, done March 29, 1972, entered into force September 1, 1972; 961 UNTS 187; TIAS 7762; 24 UST 2389; UKTS 1974 No. 16; Cmnd. 5068; ATS 1975 No. 5; 10 ILM 965 (1971); and (4) the Convention on Registration of Objects Launched into Outer Space (hereafter Registration Convention), New York, done January 14, 1975, entered into force September 15, 1976; 1023 UNTS 15; TIAS 8480; 28 UST 695; UKTS 1978 No. 70; Cmnd. 6256; ATS 1986 No. 5; 14 ILM 43 (1975).
}

With the gradual involvement of the private sector in the undertaking of space activities all that changed. In this second era, private entities started to offer launch services or operate space objects themselves. In legal terms this raised the need for individual states to exercise jurisdiction over them in order to fulfill the latter's international responsibility and liability in accordance with the space treaties. As one consequence, from the early 1980s onwards, slowly but inexorably states started to enact national space laws, licensing systems and other supervision mechanisms vis-à-vis private space operators, to ensure that the latter's operations would be under legal control of the former.

Until recently, however, manned spaceflight was not part of this process, being much more technologically demanding and expensive. It was basically beyond the reach of private entities to act in this context as the provider of launch services and the operator of the spacecraft (two roles usually combined in the context of manned spaceflight). Also, until Dennis Tito's flight to the ISS in 2001 proved otherwise, the price was simply considered to be prohibitive for private persons. The international space treaties, as augmented by national space legislation, regulation and governance still essentially sufficed to properly contain private space activities.

Space tourism, then, represents a third era, in that now the aforementioned privatization has also reached the area of manned spaceflight. In addition to the possibility that the manufacturer of the vehicle or the insurer might be a private party, still essentially subsumed under their state's jurisdiction, responsibility and liability as far as international space law is concerned, now the provider of the launch services, the operator of the space object, and/or the humans so transported may be private.

These particular novelties introduce a whole range of new legal issues, for example with contracts being concluded regarding spaceflights between passengers and/or the entities paying for their flights on the one hand, and operators, whether public (as in the case of flights to the ISS) or private (as in the case of suborbital flights into the edge of space expected to take off soon), on the other. In short, the most important and certainly most striking key legal aspects of space tourism stem from the dichotomy between the public character of international space law and the thoroughly private character of 'space tourism.' The former reflects the origins of space activities as largely driven by political/military factors and scientific interest. Even after private and commercial interests became a major aspect of certain parts of the space arena, it was largely through concepts of state responsibility and state liability and the consequent 
implementation by national space law that such interests were legally dealt with-never, so far, by creating something akin to private international law. Space tourism therefore takes commercialisation and privatization one key step further. Its very essence is that anything involved in manned spaceflight - the manufacture of vehicles, launch and other in-space operations, marketing and provision of services, and most prominently of course the space travellers themselves - could well be truly private.

This paper will thus discuss some key legal aspects of authorization and supervision, liability and registration, as most clearly emanating from the international space treaties, and how they reflect and affect space tourism. One other set of key legal aspects, those of certification of craft, crew, and passengers, while not yet much articulated at the international level will also be touched upon precisely in order to demonstrate that the legal developments referred to, as a consequence of their totally private character, could well be driven first and foremost by national legislative interests on a domestic level, before (possibly) reaching the level of international law.

\section{2. 'Space Tourism' versus 'Private Spaceflight': The Definitional Issue}

First, however, it is important to realise that the label of 'space tourism,' while perhaps an easy term for the spaceflights at issue, ${ }^{2}$ is not an altogether legally precise one. It is true that all privately funded flights of humans which have taken place so far or are expected in the near future have received this label-but not in some cases without dispute.

On the one hand, space tourism has so far concerned orbital space tourism, starting with Tito's week-long visit to the ISS's Russian module in April 2001 at a ticket price of some US\$20,000,000 and so far having seen six more space tourists enjoying a similar ride. ${ }^{3}$ While this is still about public spacecraft (Soyuz vehicles) travelling to public destinations (the ISS), the private character of the passengers as well as of broker Space Adventures clearly sets these flights apart from other trips on a Soyuz or other visits to the ISS in terms of handling state responsibility and liability. As long as it is unlikely that a rich private organization becomes interested in funding such a trip for clearly non-tourist purposes (a science mission not paid for by any public agency, for example) all private orbital activities will one way or another amount to 'space tourism.' Neverthtless, the second such 'orbital space tourist,' Mark Shuttleworth, made a point of emphasising that he was also taking a number of small scienti.c experiments with him on his trip, and did not want to be called a 'tourist' at all. ${ }^{4}$ On the other hand, suborbital tourism formally speaking is yet to take off, although the events following the Scaled Composites win of the X-Prize in October 2004 make it likely that within the next few years the first few-hour trips to the edge of outer space and back will be offered, at ticket prices in the range of US $\$ 100,000$ to 200,000 . While there is no proper 'tourist destination' in outer space involved, the spacecraft are completely financed, owned and operated on a private basis (by Virgin Galactic, XCOR, Rocketplane or similar companies). Thus, legally speaking, this presents the next step in private manned spaceflight. The term 'space tourism' still seems appropriate, as it would be unlikely for any other private person than a 'tourist' to be prepared to pay for what essentially amounts to a sophisticated bungee jump. Again, however, the operators certainly are not only looking for clients among people interested in travelling into or in outer space for fun, but also for space agencies willing

\footnotetext{
${ }^{2}$ See e.g. S. Freeland, Up, Up and ... Back: The Emergence of Space Tourism and Its Impact on the International Law of Outer Space, 6 Chicago Journal of International Law (2005), 6; S. Hobe \& J. Cloppenburg, Towards a New Aerospace Convention? Selected Legal Issues of "Space Tourism," in Proceedings of the Forty-Seventh Colloquium on the Law of Outer Space (2005), 377-8.

${ }^{3}$ Namely Shuttleworth in 2002, Olson in 2005, Ansari in 2006, Simonyi in 2007 and 2009, Garriott in 2008, and Laliberté in 2009.

${ }^{4} \mathrm{Cf}$. also Freeland, 3.

${ }^{5}$ Cf. e.g. R. Abeyratne, Space Tourism - Parallel Synergies Between Air and Space Law?, 53 Zeitschrift für Luft- und Weltraumrecht (2004), $184 \mathrm{ff.}$
}

to pay for the training of astronauts or others willing to pay for small experiments enot touristic activities in any normal sense of the word.

This already makes clear that the label of 'space tourism' is too limited as a legal category: its focus on the motivation (for pleasure, as opposed to science or training) as the decisive criterion to set these activities apart from more traditional spaceflight is a doubtful legal distinguisher. For purposes of air law (one of the areas of law often referred to in the context of legal issues concerning space tourism5), for example, the motivation for someone to take a flight is basically irrelevant. On board an aeroplane businessmen, politicians, scientists, charity workers and tourists are all treated exactly the same, legally speaking; where the legal status and regime of the flight or craft is concerned, it does not matter one jot whether the plane is filled with the one or the other. It is interesting to note in this context, moreover, that Virgin Galactic, the company generally considered closest to actually offering private flights into the edge of space, intends to use 'space tourism' as a technology demonstrator for suborbital travel, where these forms of spaceflight will become much more akin to aviation.

Thus, a third category of non-traditional space activities comes into the picture, to which the label of 'tourism' fits only with great difficulty: that of proper private suborbital spaceflight, where the main aim is to offer private persons the possibility to fly on board private vehicles from one place to another, in the process entering, traversing and leaving the edge of outer space for the purpose of making enormous time gains. While in the further future, with plans such as those by Bigelow Aerospace to build, launch and operate a space hotel, one might soon also see private destinations in outer space arise as yet another kind of private spaceflight, this paper will focus on the three categories mentioned above, using the term of 'private spaceflight' as the proper and legally precise overarching label to start an in-depth discussion and analysis. ${ }^{6}$

Such 'private spaceflight' is consequently defined as: "Flights of humans intended to enter outer space (a) at their own expense or that of another private person or entity, (b) conducted by private entities, or (c) both." It thus hinges on two alternative specific criteria setting it apart from other, more traditional space activities; two criteria which may also apply together: the humans being transported are private individuals and responsibility for the conduct of the flight is private. It is this fundamentally private character, as defined by the two alternative criteria, which sets private spaceflight apart from manned spaceflight paid for and operated by the public sector, whether national or intergovernmental, and which raises an array of new legal issues that the future legal framework should address.

The first key criterion, in its reference to "their own expense or that of another private person or entity" excludes only the transport of professionals engaged by public agencies to flyin space (unless, of course, the operator is a private entity under the second key criterion). ${ }^{7}$ Thus, first it encompasses all space tourists paying for themselves, while, second, payment for (part of) the flight by another private entity, such as an airline offering the flight against an amount of frequent flyer miles or a lottery paying for the winner to fly, would also still qualify as a case of 'private spaceflight.'

The second key criterion by means of the phrase "conducted by private entities" ensures that cases of flights (partially) paid for by public entities, for example if the 'passengers' are not 'space tourists

${ }^{6}$ For a preliminary effort to analyze some of those further-reaching private spaceflight scenarios, one might refer e.g. to the author's Passing the Buck to Rogers: International Liability Issues in Private Spaceflight, 86 Nebraska Law Review (2007), 400-38.

${ }^{7}$ Such transport of professionals by public entities has no real private law element to it, as even the employment contracts of the persons involved are concluded with public employers.

${ }^{8}$ The present interim U.S. regime dealing with private commercial spaceflight makes a distinction between such trial flights and flights carrying paying passengers; however, whilst such a further distinction does make sense, both types of flights together are essentially set apart from any public flights. 
but professional astronauts, are still covered, as the operational responsibilities would continue to rest with the private entities concerned. The criterion itself thus only excludes flights operated by governmental or intergovernmental agencies. Trial flights of private operators without passengers should still qualify as such. ${ }^{8}$ Finally, the phrase "intended to enter outer space" ensures that aborted or failed flights are also included in the concept. Interestingly, while there is not yet any generally accepted definition of outer space in a legal sense (that is, at which altitude above the Earth one should start speaking about 'outer space'), the definition presumes that somewhere a legal boundary between airspace and outer space does indeed exist.

\section{Authorization and Continuing Supervision}

The traditional orientation of international space law is epitomized by Article VI of the Outer Space Treaty, establishing state responsibility for private activities on exactly the same level as it does for state activities. ${ }^{10}$ The only (double) criterion for invoking a particular state's responsibility is that the activities at issue must somehow qualify as "national activities in outer space." ${ }^{11}$ Further to this responsibility, which pertains to ensuring that the activities concerned will comply with international law, these "shall require authorization and continuing supervision by the appropriate State." 12

The main result is the need for relevant states to authorize, monitor and control those private spaceflight activities possibly giving rise to state responsibility and/or liability under the Outer Space Treaty and the Liability Convention. Indeed, several states have enacted laws and regulations dealing with private space activities in general: they include the USA, ${ }^{13}$ Russia, ${ }^{14}$ Norway ${ }_{1}^{15}$ Sweden,${ }^{16}$ France,${ }^{17}$ Australia ${ }^{18}$ and Brazil. ${ }^{19}$ All these states currently have operational launch facilities on their territory which could in principle be made available for commercial launches.

However, in terms of plausible launch sites for private spaceflights certainly not all options are covered. Such states as Singapore and the United Arab Emirates, presumably harboring serious plans to offer private spaceflight launch capabilities, have no comprehensive national space law or regulation in place, whereas the Dutch Antilles are currently not covered by the scope of the Dutch Space Activities

\footnotetext{
${ }^{9}$ See on this issue further infra, para. 3.

${ }^{10}$ It applies regardless of "whether such activities are carried on by governmental agencies or by non-governmental entities," in effect ignoring the distinction prevailing in general public international law between state acts for which a state is 'directly responsible' and private acts of, e.g., its citizens for which a state can at best be held responsible 'indirectly,' vicariously' or 'due care;' Art. VI, Outer Space Treaty. See, e.g., A. Cassese, International Law (2001), 184, 187-91; M. Akehurst, A Modern Introduction to International Law (5th ed.) (1984), 88-9; R.M.M. Wallace, International Law (3rd ed.)(1997), 176-8.

${ }^{11}$ Art. VI, Outer Space Treaty; emphasis added.

${ }^{12}$ Art. VI, Outer Space Treaty.

${ }^{13}$ Of prime relevance here is the Commercial Space Launch Act, codified as Commercial Space Transportation-Commercial Space Launch Activities, 49 U.S.C. 70101 (1994)

${ }^{14}$ Law of the Russian Federation on Space Activities, No. 5663-1, August 20, 1993, effective October 6, 1993; National Space Legislation of the World, Vol. I (2001), at 101.

${ }^{15}$ Act on launching objects from Norwegian territory into outer space, No. 38, June 13, 1969; National Space Legislation of the World, Vol. I (2001), at 286.

${ }^{16}$ Act on Space Activities, 1982: 963, November 18, 1982; National Space Legislation of the World, Vol. I (2001), at 398; Space Law - Basic Legal Documents, E.II.1; 36 Zeitschrift für Luft- und Weltraumrecht (1987), at 11.

${ }^{17}$ Law on space activities (Loi relative aux opèrations spatiales); Loi no $2008-518$ du juin 3, 2008; 34 Journal of Space Law (2008), at 453 (unofficial translation).

${ }^{18}$ An act about space activities, and for related purposes, No. 123 of 1998, assented to December 21, 1998; as amended by amending legislation up to No. 100 of 2002.

${ }^{19}$ Administrative Edict No. 27, June 20, 2001; National Space Legislation of the World, Vol. II (2002), at 377 .

${ }^{20}$ See Law Incorporating Rules Concerning Space Activities and the Establishment of a Registry of Space Objects, January 24, 2007; 80 Staatsblad (2007), at 1 .
}

Act. ${ }^{20}$ So far, moreover, only the U.S.A. has taken the next step of adapting such general national space law to the specifics of private spaceflight..$^{21}$ The general problem of how to determine when an activity might be considered 'national' for the purpose of international responsibility has been discussed ever since private space activities became prominent enough to require domestic legislative action in that context. In that sense, private manned space activities such as space tourism do not bring anything new to the discussion.

Thus, the impact of the uncertainties resulting from the absence of a generally accepted definition of 'national activities' on private spaceflight is in principle no different from that on private space activities in general. Here, individual states have simply followed their own preferences regarding when and how to apply national jurisdiction for the purpose. Even in the context of the European Union, with member states generally accepting the overarching priority of EU law in many areas, the Treaty of Lisbon, which makes formal reference for the first time to EU competence in the field of space activities, expressly prohibits any EU-level efforts to harmonize national regulations regarding private space activities. ${ }^{22}$

By contrast, with reference to the other element of the double criterion - whether the national activities concerned constitute 'activities in outer space' - the rise of space tourism does bring some novel issues, and perhaps even a certain level of urgency, to the table. The International Civil Aviation Organisation (ICAO) ${ }^{23}$ has started to discuss its own possible role with respect to suborbital flights, whether tourist or not, but so far has refrained from actually initiating regulatory developments in this area. ${ }^{24}$ Likewise, the European Aviation Safety Administration (EASA) ${ }^{25}$ which considers the vehicles to be used for suborbital flight 'aircraft,' since they are winged and use the upward lift of the air, is about to develop a certification regime for such vehicles on the basis of aircraft certification. ${ }^{26}$

This is where the discussion on where outer space begins (as relative to underlying airspace), so far rather theoretical in view of the unwillingness of a number of states to discuss agreement on a certain altitude being the 'boundary' between the two realms, comes back to haunt the legislative community. Other states have been pushing for such a boundary, ${ }^{27}$ but aircraft able to fly close to the limit of

\footnotetext{
${ }^{21}$ By means of the Commercial Space Launch Amendments Act, Public Law 108492, 108th Congress, December 23, 2004, 49 U.S.C.; 118 Stat. 3974, and implementing regulation. Note again that this legislation is explicitly announced to be of a temporary nature; see e.g. Study of the Liability Risk-Sharing Regime in the United States for Commercial Space Transportation, Aerospace Report No. ATR2006(5266)-1, of August 1, 2006, for the U.S. Department of Transportation, 1, 4 .

${ }^{22}$ See Art. 189(2), Treaty of Lisbon amending the Treaty on European Union and the Treaty establishing the European Community (hereafter Treaty of Lisbon), Lisbon, done December 13, 2007, entered into force December 1, 2009; OJ C 306/1 (2007).

${ }^{23}$ ICAO was established by the Convention on International Civil Aviation (hereafter Chicago Convention), Chicago, done 7 December 1944, entered into force April 4, 1947; 15 UNTS 296; TIAS 1591; 61 Stat. 1180; Cmd. 6614; UKTS 1953 No. 8; ATS 1957 No. 5; ICAO Doc. 7300 in particular to develop an international regime for the safety of aviation, and has since developed many Standards and Recommended Practices to implement that mandate. See e.g. R.S. Jakhu \& Y.O.M. Nyampong, International regulation of emerging modes of space transportation, in J. Pelton (Ed. ), Space Safety Regulations and Standards (2010), 215-38.

${ }^{24}$ See Working Paper on Concept of Suborbital Flights, ICAO Council, 175th Session, May 30, 2005, C-WP/12436; further e.g. P. van Fenema, Suborbital Flights and ICAO, 30 Air \& Space Law (2005), 396-411; P.S. Dempsey \& M.C. Mineiro, Space Traffic Management: A Vacuum in Need of Law, Paper IAC08-E3.2.3, 59th International Astronautical Congress, Glasgow, 2008.

${ }^{25}$ EASA was established by the Regulation of the European Parliament and of the Council on common rules in the field of civil aviation and establishing a European Aviation Safety Agency (No. 1592/2002/EC, of July 15, 2002; OJ L 240/1 (2002)), in order inter alia to replace the Joint Aviation Authorities in its role of certifying aircraft and licensing air crews as well as strengthening that role.

${ }^{26}$ See e.g. J.B. Marciacq et al., Towards Regulating Suborbital Flights: An Updated EASA Approach, Paper IAC-10-D2.9.5, 61st International Astronautical
} Congress, Prague, 2010; also Hobe \& Cloppenburg, 379. 
atmospheric extension are essentially absent, as are satellites able to orbit below it, which has so far allowed the international community to get away with such indecision. Spacecraft transiting to outer space only remain in the legal 'grey zone' between the area used for aircraft and what undeniably amounts to outer space for a short period of time, not necessitating specific international consensus on where exactly they move from the one to the other. The impending plans for suborbital space tourism, however, may cause many states to reconsider. The X-Prize, billed as a prize for the first private venture into outer space, called for contestants to reach an altitude of $100 \mathrm{~km}$ as the decisive criterion. Today, all companies preparing to commercialize the idea sell their flights as reaching outer space by means of achieving altitudes of over $100 \mathrm{~km}$. By doing so, these companies may at some point force a more specific determination of the issue.

Of course, the mere insistence by some private companies that the $100 \mathrm{~km}$-altitude boundary serves to label flights above that altitude 'spaceflights' with the passengers receiving astronaut certi.cates, cannot create a rule of customary international law to that effect. Yet, if the number of such flights began to build up rapidly and continuously without relevant states formally protesting or denying the validity of such private assertions, there may be a point where silence by those states comes to be seen as consent to precisely such a customary rule.

Moreover, the the Federal Aviation Administration (FAA) of the USA - the single-most important state against establishing such a boundary - grants astronaut wings to everyone having flown over 62.5 miles up (which equates with $100 \mathrm{~km}$ ). ${ }^{28}$ And the U.S. state of Virginia has been considering extending the range of its state-level jurisdiction up to a similar altitude. ${ }^{29}$ Finally, whether driven by a prospect of serving as launch territory for private spaceflight or not, Australia amended its national act in 2002 so as to assert its jurisdiction on a territorial basis up to $100 \mathrm{~km}^{30}$

It remains to be seen to what extent the specifics of suborbital space tourism might call upon states to strive for a clear-cut boundary between airspace and outer space. By its amendments to the Commercial Space Launch Act specifically addressing impending space tourist flights, the U.S.A. has so far not changed its position. U.S. jurisdiction consequently still applies to the operators and their activities not so much on the basis of where the latter might exactly take place, but of whether the launch takes place from U.S. territory and on the nationality of the operator. ${ }^{31}$

Several aspects of the uncertainty resulting from the absence of a clear-cut legal lower boundary of outer space once again emanate from existing international air law. Under the Chicago Convention, states are responsible for the safety of aviation in national airspace, which of course formally raises the question of the altitude at which 'national airspace' gives way to 'international outer space.' ${ }^{32}$ The safe passage of vehicles outside such airspace would not fall under the responsibility of the state below (unless of course it were also the state of nationality of the operator and/or of registration of the vehicle), which at least formally raises the issue of where such responsibility ends. Similarly, the need to determine which criminal law would apply to activities on board a private craft hinges partly on

\footnotetext{
${ }^{27}$ Mostly, they focused on the altitude of $100 \mathrm{~km}$ above sea level. See e.g. Dempsey \& Mineiro, 2-3; the author's The Sky is the Limit-But Where Does It End?, in Proceedings of the Forty-Eighth Colloquium on the Law of Outer Space (2006), 84-94.

${ }^{28}$ At the same time it should be noted that NASA and the U.S. Navy award such wings (already) to someone having flown up to 50 miles, or $80 \mathrm{~km}$.

${ }^{29}$ Cf. House Bill No. 3184, Amendment in the Nature of a Substitute, proposed by the House Committee for Courts of Justice on February 2, 2007; see Art. 24, Spaceflight Liability and Immunity Act, § 8.01-227.8, 'Definitions.' By contrast, the state of New Mexico defined space as "any location beyond altitudes of sixty thousand feet above the earth's mean sea level" in the Gross Receipts and Compensating Tax Act, N.M. Stat. \& 7-9-54. 60,000 feet roughly equate with $18 \mathrm{~km}$.

${ }^{30}$ See Sec. 8, An act about space activities, and for related purposes, as amended 2002. Further Freeland, 8-9.

${ }^{31}$ Cf. Sec. 70104(a)(1) \& (2), Commercial Space Launch Act.
}

where the airspace of the state below it may be deemed to end, vertically speaking. The Tokyo Convention effectively provides that the state in whose airspace an aircraft registered with another state is flying is the primary state entitled to exercise its "criminal jurisdiction over an offence committed on board," although the said state should not do so unless other criteria apply. ${ }^{33}$

As long as private spaceflights only dip into the extreme lower end of outer space-Virgin Galactic for example aims for an altitude of some $120 \mathrm{~km}$ - for just a few minutes and do not stray above other states, this may not be too much of a problem. However, ultimately when the step from suborbital space tourism to suborbital spaceflight is taken, and spacecraft en route from New York to Sydney start passing over some third states at altitudes above those used by (conventional) aircraft but below those used by orbiting satellites, the issue will have to be comprehensively addressed.

\section{Liability}

The state-orientation of international space law as point of departure for the international legal regime for private spaceflight is also re.ected by the concept of state liability, as per Article VII of the Outer Space Treaty and the Liability Convention. The former already provided for state liability for damage caused by space objects attaching to a state fundamentally involved in the launch of the space object in question. ${ }^{34}$

The first issue which private spaceflight raises to a new level of discussion concerns the definition of 'space object,' as it triggers the application of the space law liability regime, and its applicability to the vehicles to be used for suborbital tourism and spaceflight. The Liability Convention itself is not very helpful, as its definition is fairly open-ended - and partly circular at that. ${ }^{35}$ In addition, experts agree that a space object is any man-made object launched or intended to be launched into outer space. ${ }^{36}$

As indicated, however, in discussing applicability of its competences, EASA has already provisionally decided to treat suborbital vehicles as 'aircraft.' ${ }^{37}$ Although this does not necessarily negate the possibility of also defining these vehicles as space objects under space law for the purposes of liability, it certainly makes things more complicated. So far, the general approach is to consider them (also) as space objects triggering applicability of the Liability Convention, ${ }^{38}$ but it might soon become necessary to establish more clarity and certainty, if not indeed coherence in that respect.

${ }^{32}$ Cf. Art. 28, Chicago Convention. ${ }^{33}$ Namely, if "(a) the offence has effect on the territory of such State; (b) the offence has been committed by or against a national or permanent resident of such State; (c) the offence is against the security of such State; (d) the offence consists of a breach of any rules or regulations relating to the flight or maneuver of aircraft in force in such State; [or] (e) the exercise of jurisdiction is necessary to ensure the observance of any obligation of such State under a multilateral international agreement;" Art. 4, in conjunction with Art. 1(2), Convention on Offences and Certain Other Acts Committed on Board Aircraft (hereafter Tokyo Convention), Tokyo, done September 14, 1963, entered into force December 4, 1969; 704 UNTS 219; UKTS 1969 No. 126; Cmnd. 2261; ATS 1970 No. 14; 2 ILM 1042 (1963); ICAO Doc. 8364.

${ }^{34}$ Art. VII, Outer Space Treaty, provides a fourfold criterion, later enshrined in the notion of "launching State" (Art. I(c), Liability Convention): "Each State (...) that launches or procures the launching of an object into outer space (...) and each State Party from whose territory or facility an object is launched."

${ }^{35}$ Art. I(d), Liability Convention, provides: "The term 'space object' includes component parts of a space object as well as its launch vehicle and parts thereof."

${ }^{36} \mathrm{Cf}$. also the formulations of Artt. VII, VIII, Outer Space Treaty; the full title of the Rescue Agreement; Art. V(1), Liability Convention; and more generally the use of the word 'launching' throughout the Convention.

${ }^{37}$ The generally accepted ICAO definition contained in Annex 8 to the Chicago Convention states that "any machine that can derive support in the atmosphere from the reactions of the air other than the reactions of the air against the earth's surface" qualifies as an aircraft. This would certainly include a number of the vehicles currently being designed and developed for suborbital flights. 
Furthermore, the net result of the apportionment of liability to states crucially involved in the launch is that such apportionment takes place regardless of any private involvement in any relevant aspect or stage of the space activity concerned. The reference to 'territory' as one of the four criteria concerned in legal terms can only point to a state. As for the other three criteria (the activity of 'launching' itself, the 'procurement of the launch' and the 'facility for the launch'), there is no clarity about whether a state can become liable merely on account of one of its citizens, whether a natural or juridical person, being the launch operator, the procurer of the launch or the launch facility operator. Experts differ in their opinion, and more importantly, so do the states that so far have had to deal with this. ${ }^{39}$ Given that the essential distinguishing factor of private spaceflight as argued, is the private character of its operators and/or passengers, the issue becomes especially relevant if such flights come to be launched not from any state's territory ${ }^{40}$ nor from a governmental (or intergovernmental ${ }^{41}$ ) launch facility, nor on a governmental (or intergovernmental) launch vehicle. Since for private spaceflight as defined 'procurement' would by definition be a private matter, this again brings to the fore the question of the scope of application of the criteria for becoming a "launching State" under the Liability Convention: a narrow reading might preclude the possibility to hold any state liable under the Liability Convention - and private parties themselves can neither sue nor be sued under that treaty. ${ }^{42}$

With private spaceflight fundamentally raising the level of private involvement on all counts, this is an issue that can no longer be neglected. Such flights will soon be confronted with the much higher safety requirements that manned spaceflight imposes, not only to protect humans on board but also because of human spaceflight's public visibility. Liability will only be a part of this, though an important one. Third-party liability and related issues such as insurance have already been involved in the second era of human space activities, and in general terms have been dealt with by relevant domestic legislative developments implementing the international treaties in this respect. In the U.S.A., the state most elaborately and fundamentally dealing with private involvement in space transportation, the original version of the Commercial Space Launch Act was enacted as early as $1984 .^{43}$

Nevertheless, the private character of operations now requires a much higher level of control and monitoring. The perception, rightly or wrongly, that private flights would largely be undertaken for the benefit of 'space tourists' and not serve any clear public purpose such

\footnotetext{
${ }^{38} \mathrm{Cf}$. in this respect also the U.S. approach of treating suborbital flights under the Commercial Space Launch Act, even if as amended, with licensing competences principally residing with the Administrator for Space Transportation within the FAA.

${ }^{39}$ See e.g. F. von der Dunk, Private Enterprise and Public Interest in the 'European Spacescape' (1998), 130-1 on Sweden's Act on Space Activities; 134-7 on the United Kingdom's Outer Space Act (July 18, 1986, 1986 Chapter 38; National Space Legislation of the World, Vol. I (2001), at 293; Space Law - Basic Legal Documents, E.I; 36 Zeitschrift für Luft- und Weltraumrecht (1987), at 12); 142-4 on Russia's Law of the Russian Federation on Space Activities; and 149-51 on South Africa's Space Affairs Act (6 September 1993, assented to on June 23, 1993, No. 84 of 1993; Statutes of the Republic of South Africa - Trade and Industry, Issue No. 27, 21-44; National Space Legislation of the World, Vol. I (2001), at 413).

${ }^{40}$ In terms of unmanned space launches, there is the example of Sea Launch an internationally structured consortium launching from the high seas, operating since the late nineties as a reminder that sooner or later this might happen for private spaceflight, too.

${ }^{41}$ To a considerable extent the Kourou spaceport in French Guyana could be considered an ESA-launch facility, even if France and the French space agency CNES maintain a fundamental share of ownership and operational responsibility for any launch taking place there. See Art. XXII, Liability Convention, and Declaration of September 23, 1976; International Organisations and Space Law (1999), at 33

${ }^{42}$ As the Convention itself provides, however, nothing stands in the way of a private party to address a claim to any defendant, or vice versa of a state to address a claim to a private defendant, in the courts of a launching state; see Art. XI(2), Liability Convention.
}

as science or security will also contribute to the implementation of much more detailed elaborations of existing regimes. In the U.S.A., consequently, the Commercial Space Launch Act was amended by the Commercial Space Launch Amendments Act of 2004, ${ }^{44}$ which in turn was followed by frequent regulatory activities of the U.S. licensing authorities updating the Code of Federal Regulations on these points. As we shall see, the issue of liability was a fundamental part of that extension of the legal regime.

\section{Registration}

The third cornerstone of international space law in the context of private space activities concerns the registration of space objects, which under Article VIII of the Outer Space Treaty entitles the state of registry to maintain jurisdiction and control over such space objects in outer space, as well as over any "personnel thereof." In this context, the discussion of whether a private tourist might qualify as an 'astronaut' or as 'personnel' on a spacecraft, is to be noted. ${ }^{45} \mathrm{~A}$ general tendency can be seen to separate the legal status of 'true' astronauts, as persons selected and rigorously trained in the service of a governmental or intergovernmental space agency for public purposes, from that of others, most notably private individuals mainly going to outer space for their own private pleasure.

This would be in line with the distinction between 'astronauts' and 'spaceflight participants' already made in one pertinent case of international law and in one of national law. This fundamental distinction was made in the 2001 Principles for processes and criteria for selection, assignment, training and certification of ISS (expediting and visiting) crew under the 1998 Intergovernmental Agreement ruling the ISS, ${ }^{46}$ the only multilateral space treaty on manned spaceflight beyond the Rescue Agreement that comprises most of the major spacefaring nations ${ }^{47}$ Similarly, in the U.S. case the 2004 Commercial Space Launch Act Amendments also refers to the concept of 'spaceflight participants' as requiring levels of regulation different from traditional astronauts. ${ }^{48}$

Such a distinction between 'true' astronauts and 'spaceflight participants' may soon become generally accepted in international space law. While making considerable sense, creating that distinction would - and I believe should - not lead to a distinction regarding the extent to which jurisdiction can be exercised.

It is true that Article VIII of the Outer Space Treaty provides for jurisdiction over "space objects and personnel thereof" only. Should space tourists escape such jurisdiction simply on account of their not being 'personnel'? Under the Vienna Convention on the Law of Treaties a contextual interpretation of Article VIII in order to avoid

\footnotetext{
${ }^{43}$ Public Law 98-575, 98th Congress, H.R. 3942, October 30, 1984; 98 Stat. 3055; Space Law - Basic Legal Documents, E.III.3.

${ }^{44}$ Public Law 108-492, 108th Congress, December 23, 2004, 49 U.S.C.; 118 Stat. 3974.

${ }^{45}$ Cf. e.g. Art. V, Outer Space Treaty, as well as the Rescue Agreement; further e.g. Freeland, 10-1; Abeyratne, 186-7; M. Sundahl, The Duty to Rescue Space Tourists and Return Private Spacecraft, 35 Journal of Space Law (2009), 163-200.

${ }^{46}$ Agreement among the Government of Canada, Governments of Member States of the European Space Agency, the Government of Japan, the Government of the Russian Federation, and the Government of the United States of America concerning Cooperation on the Civil International Space Station (hereafter Intergovernmental Agreement), Washington, done January 29, 1998, entered into force March 27, 2001; Space Law - Basic Legal Documents, D.II.4.

${ }^{47}$ Cf. e.g. the analysis in F.G. von der Dunk \& G.M. Goh, Article V, in S. Hobe, B. Schmidt-Tedd \& K.U. Schrogl (Eds.), Cologne Commentary on Space Law, Vol. I: Outer Space Treaty (2009), 96-7; R. Veldhuyzen \& T.L. Masson-Zwaan, ESA Policy and Impending Framework for Commercialisation of the European Columbus Laboratory Module of the ISS, in F.G. von der Dunk \& M.M.T.A. Brus (Eds.), The International Space Station: Commercial Utilisation from a European Legal Perspective (2006), 47, 54-5.

${ }^{48}$ See Sec. 70105(b)(2)(D), Commercial Space Launch Act, as amended 2004 by the Commercial Space Launch Amendments Act, Public Law 108-492, 108th Congress, December 23, 2004, 49 U.S.C.; 118 Stat. 3974. See e.g. Von der Dunk \& Goh, 97.
} 
"a result which is manifestly absurd or unreasonable" is allowed, ${ }^{49}$ which, it is submitted, requires viewing the phrase "and personnel thereof" as applying also to'non-personnel,' that is private passengers. It should be added that jurisdiction over the space object as such already extends to everyone on board, meaning that the addition of "and personnel thereof" essentially targets extravehicular activities only. Beyond Article VIII of the Outer Space Treaty, the Registration Convention, which at the international level takes care of registration issues further to that Article, does not at this moment provide for specific issues relating to private spaceflight or space tourism. In other words, the aforementioned discussion on applicability of the launching state-criterion under the Liability Convention in a context where private operators launch, procure the launch and/or own the launch facility is relevant in this context as well, just as the obligations under the Registration Convention principally rest upon the shoulders of the launching state(s). ${ }^{50}$

The issue of defining spaceflight vehicles as 'space objects' so as to trigger applicability of the Registration Convention, does not raise any issues additional to those raised by the Liability Conventionexcept for one. While the Registration Convention does seem to target all space objects (intended to be) launched into outer space, it effectively only requires registration of such space objects when "launched into Earth orbit or beyond," ${ }^{51}$ meaning that space objects launched on suborbital flight trajectories remaining below (that is: not "beyond") an altitude considered 'Earth orbit' (whatever that might be) would not be covered by that obligation. This, of course, was conducive to both ICAO and EASA starting discussion of the applicability of their respective competences to suborbital flights, e.g. in terms of registration of the vehicles concerned as aircraft. ${ }^{52}$ It remains to be seen, however, whether this is a beneficial development or approach with a view to the overall coherence of international space law.

\section{Certification}

In addition to the issues discussed above, which, though of distinctive importance for private spaceflight, derive from the international space treaties and their domestic implementation in general, private spaceflight also gives rise to a new set of issues, so far outside the context of those treaties - and even of space law as a whole.

The private operation of manned spacecraft now calls for the application of concepts well-known in aviation, such as safety certification of the vehicles and the hard- and software involved, and licensing of the crew involved in flying the spacecraft, at least in princi$\mathrm{ple}^{, 53}$ something not considered necessary as long as the transportation was essentially undertaken by public agencies. In addition, concepts such as 'wet lease' and 'dry lease' and their respective legal consequences might now become involved. ${ }^{54}$ Finally, with the advent of paying passengers on the scene, their contractual arrangements will also deal with contractual liability or waivers thereof, with gross negligence and with wilful misconduct, all this partly in relation to certification issues.

Here it is interesting to note that the U.S.A. has addressed the latter issue by way of the aforementioned interim regime calling for passengers to set down in writing their 'informed consent' to flying on a vehicle that is non-certi.ed and essentially without a safety track record, implying that no liability claims would lie against the operator if a flight were to result in an accident. ${ }^{55}$ In other words, rather than imposing certification, the U.S. regime is one of non-certification, leading to an absence of contractual liability as long as the 'informed consent' requirement is complied with.

\footnotetext{
${ }^{49}$ Cf. Art. 32, Vienna Convention on the Law of Treaties, Vienna, done May 23, 1969, entered into force January 27, 1980; 1155 UNTS 331; UKTS 1980 No. 58; Cmnd. 4818; ATS 1974 No. 2; 8 ILM 679 (1969).

${ }^{50}$ See Artt. I(a), II, IV, Registration Convention.

${ }^{51}$ Art. II(1), Registration Convention. Cf. also Art. IV(1)(d), requiring information on the basic orbital parameters.

${ }^{52}$ Cf. Art. 17-21, Chicago Convention.
}

So far this would only seem to be an issue in a national U.S. context, given the crucial involvement of U.S. entrepreneurs as well as U.S. legislators and regulators in all impending projects for private commercial manned spaceflight. Nevertheless, it may be noted that one of the pilots carrying out the experimental flights for the X-Prize that led to the establishment of Virgin Galactic was a Scot. Furthermore, Virgin Galactic has concluded deals to start launching in Sweden and the United Arab Emirates, while Space Expedition Curaçao, a Dutch company, is planning to start launching from the Dutch Antilles, all within a few years from now. Less developed plans also exist to start private commercial manned spaceflights from Catalonia, the middle of France, Hokkaido island in Japan and Singapore. Finally, it should be reiterated that both ICAO and EASA are closely following such developments in order to determine whether, when and to what extent they should regulate such flights or certain aspects thereof.

So while there may as yet be no international space law which applies in the area of certification, there are developments in international air law which are of impact. Although at the national level the U.S. regime is essentially one of non-certification, it is expressly of an interim nature, with a sunset requirement of being revisited ultimately by December 2012 under the Commercial Space Launch Amendments Act of 2004. It should be added, meanwhile, that this sunset clause now looks like being extended for a few years, as so far since 2004 no further experience has been gained with private suborbital flight.

Finally, it may be noted that both the Russian and the Ukrainian national space laws have provided for obligations related to certification of spacecraft, regardless of whether private commercial operators or passengers are concerned. Thus, in the case of Russia, "[s] pace technics, including space objects, and ground and other objects of space infrastructure created for scientific and national-economy purposes, shall be checked for compliance with the requirements established by legislation of the Russian Federation (certification)." To organize such certification constitutes a major task of the Russian Space Agency. ${ }^{57}$ Certificates issued will go a long way to complying with the requirement to submit "documents confirming the safety of space operations (including ecological, fire and explosion safety) and the reliability of space equipment" in order to obtain a licence. ${ }^{58}$

Similarly, in the Ukrainian case, "[a]ny object of space activity in the Ukraine is certificated on conformity to the requirements of operational suitability established by normative documents acting in the Ukraine, with registration of the certificate of conformity." ${ }^{59}$ Such a 'certificate of conformity' is a "document which certifies conformity of object of space activity to the requirements of operational suitability of space engineering regulated by the normative documents

\footnotetext{
${ }^{53}$ In the U.S.A., the decision was made not-yet - to develop any certification or crew-licensing requirements in this context, mainly because of the lack of knowledge on what this new type of activity would actually and reasonably require in this area. Thus, the operators are authorized to fly as long as their passengers declare they are aware that they are flying on an uncertified craft with no or little track record, so-called 'informed consent.' However, as that decision was explicitly made on a temporary basis, it is expected that following the expected growth of experience, with actual flights starting soon, the responsible U.S. authorities will develop such a certification and licensing regime.

${ }^{54}$ E.g. a wet lease agreement might be a useful tool to initiate those activities when the pool of entities able to provide the technical and operational expertise as well as the hardware and software required is fairly limited. The concepts of wet lease and dry lease are of course well-known in aviation; cf. e.g. Art. 39, Convention for the Unification of Certain Rules for International Carriage by Air (Montreal, done May 28, 1999, entered into force November 4 2003; ICAO Doc. 9740; 48 Zeitschrift für Luft- und Weltraumrecht (1999), at 326).

${ }^{55}$ See further e.g. R. Yates, Minimizing Regulation of Space Tourism to Stimulate Commercial, Private Launch Capabilities, in Proceedings of the FortyNinth Colloquium on the Law of Outer Space (2007), 61, ff.; T. Knutson, What is "Informed Consent" for Space-Flight Participants in the Soon-to-Launch Space Tourism Industry?, 33 Journal of Space Law (2007), 105-22.
} 
being in force in the Ukraine." ${ }^{60}$ The National Space Agency of the Ukraine is to oversee this certification process ${ }^{61}$

In short, sooner or later private spaceflight will force debate at an international level over whether, and if so, how space law should deal with such fundamental issues as certification of the vehicles involved. Whether ultimately based on or effectively pre-empted by (international) aviation certification law, the future regime should accommodate the specifics of suborbital spaceflight, if the sector is to take off properly.

\section{Concluding Remarks}

As a consequence of the state-orientation of current international space law the legal position of private operators and their activities in the context of private spaceflight is largely defined through states, notably those bearing international responsibility and liability for their activities and able to exercise jurisdiction over themwhether or not through the instrument of registering the vehicles involved. That process is usually given concrete form through national space laws with a licensing obligation and system forming a key part thereof.

Future aspects of space tourism that may soon need to be discussed, such as certification and space traffic management, will probably have to proceed within this same paradigm, at least in the initial phases. It seems unlikely that the state-orientation will disappear soon, even if we may expect some private law approaches to take hold in international space law. At the national level, this has of course already started to occur, albeit so far only in the U.S.A. in any substantial sense.

However, once the next step has been taken, from suborbital space tourism to private suborbital spaceflight, such issues will have to be dealt with on the international level, just as has happened in air law. Space traffic management and certification in this context, like some key elements of authorization, control, liability arrangements and registration issues, cannot be dealt with on a domestic level alone, if a safe and viable industry is to develop.

${ }^{56}$ Art. 10(1), Law of the Russian Federation on Space Activities.

${ }^{57}$ See Art. 6(2), 6th bullet, Law of the Russian Federation on Space Activities.

${ }^{58}$ Art. 5(h), Statute on Licensing Space Operations, February 2, 1996.

${ }^{59}$ Art. 12, Law of the Ukraine on Space Activities, No. 502/96-VR, November 15, 1996; National Space Legislation of the World, Vol. I (2001), at 36.

${ }^{60}$ Art. 1, 9th bullet, Law of the Ukraine on Space Activities.

${ }^{61}$ See Art. 6, 7th bullet, Law of the Ukraine on Space Activities. 